\title{
Land feud holds up work on ESO's telescope in Chile
}

Munich. Building work on Mount Paranal in northern Chile, where the European Southern Observatory (ESO) plans to install the world's largest telescope, has started again after a three-week enforced stoppage, which has cost millions of marks and prompted ESO to look around for a new site.

A local court at Taltal, near Paranal, last Friday (15 April) withdrew an injunction against the construction company SkanskaBelfi which had been brought by a Chilean family claiming ownership of the land. But the family remains determined to continue its fight through the courts.

The dispute is a blow to the construction of the Very Large Telescope (VLT), a series of four $8.2-\mathrm{m}$ optical dishes estimated to cost DM463 million(US\$275 million) which has already had its completion date put back because of complaints from ESO's eight member states that its costs had grown too high (see Nature 367, 4; 1994).

Mount Paranal was donated to ESO by the Chilean government in 1988 after a search into the ownership convinced it that the site was the government's to give. The government also guaranteed ESO immunity from local law, as is normal for an intergovernmental organization.

But the Latorre family, which claims to be the direct descendants of an admiral who was given the land in the late nineteenth century in recognition of acts of heroism in

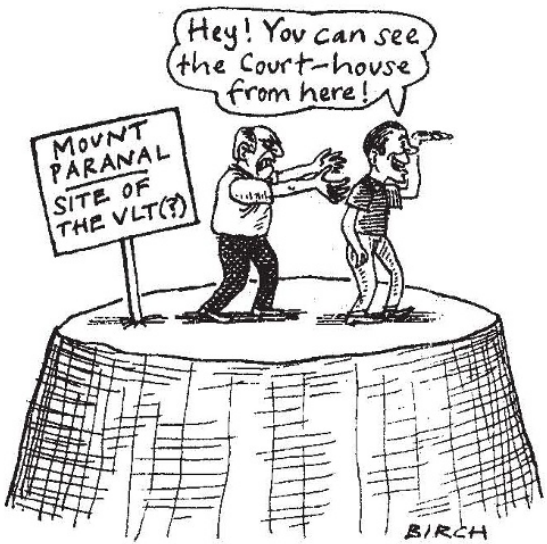

a war with Peru, insists that it retains the title to the property.

Demanding the departure of ESO from the mountain, the family took both the observatory and the government to another local court, in Antofagasta, last May. But rather than ruling on this issue, the court questioned the immunity of ESO from any future ruling it might make.

ESO challenged this decision, setting up a chain of appeals and counter-appeals that ended up in the higher supreme court. Two weeks ago, different court members issued four contradictory judgements within days of each other. A final decision from the full court is expected within a few weeks.

Meanwhile, the Latorre family successfully applied last month for an injunction to stop building work while the case was being resolved. ESO's director, Riccardo Giacconi, says that delays to the project, which he reckons to have cost millions of marks in wages and other costs, combined with uncertainty over the outcome of the Latorres' claim, have left him no choice but to look around for a new site, possibly outside Chile.

This is despite the fact that construction is already quite advanced; the top of the mountain has been levelled and concrete foundations are about to be poured. If the VLT has to be resited, Giacconi is optimistic that ESO could reclaim the money already invested in the site through international courts. But he is reluctant to take such action. "It wouldn't get the telescope built," he says.

But the issue of substance - the true ownership of the land - has not yet been tackled by the government, whose general slowness to react has been a major point of conflict with ESO. On 15 April, ESO officials met government officials to try to persuade them to take steps to secure ESO's future at Paranal. The government is now reported to be ready to challenge the Latorre family's claim to the land.

Giacconi, who claims that the ESO has become the victim of attempts by lawyers to win compensation from the government, feels that the Chilean government has been negligent in defending ESO's interests.

The affair has erupted just as ESO was concluding negotiations over various longstanding disputes with Chilean scientists and support staff, relationships with whom have been poor for the past decade.

Tensions began to ease last year with the appointment of Giacconi, who took immediate steps to resolve two particular disputes (see Nature 363, 384; 1993). One concerns a request from Chilean astronomers for guaranteed viewing time on the VLT; this had previously been rejected but Giacconi is now offering 10 per cent of the available time.

The other dispute has been over the right to collective wage bargaining. ESO does not recognize local trade unions, but Giacconi has proposed mechanisms that would both allow collective bargaining and establish arbitration for disputes. Negotiations over both topics are in abeyance until the dispute about land ownership is settled. A similar problem at La Silla, a site also 'donated' by the Chilean government where ESO now has 15 telescopes, was settled in 1964 when ESO purchased the land from those who claimed to own it.

\section{UK parliament passes surprise ban on fetal embryos in IVF}

London. Britain's health minister, Mrs Virginia Bottomley, has jumped the gun on a top-level advisory committee by agreeing to support a parliamentary move to ban the use of embryos from aborted fetuses in fertility treatment.

Earlier this year, the Human Fertilization and Embryo Authority (HFEA), which is responsible for regulating both research on and the application of fertilization treatment, published a consultation document asking for comments on the use of fetal embryos. This followed reports that the technique is already being studied in animals and in humans in other parts of the world.

The consultation period ends in July, when the HFEA is due to draw up its recommendations to the government. Last week, however, Dame Jill Knight, Conservative member of parliament (MP) for Birmingham-Edgbaston, put forward an amendment to the Criminal Justice Bill in the House of Commons specifying that "female germ cells" taken from an embryo or a fetus should not be used "for the purposes of providing fertility services for any woman".

Despite protests from opposition members of parliament, one of whom described the decision to debate the issue before the HFEA consultation period has finished as "the worst way of legislating and of using Parliament", the resolution was adopted.

The HFEA issued a statement saying that it was prepared to accept parliament's decisions, but that consultation will continue as planned. HFEA officials pointed out that Knight's resolution is restricted to the use of embryos in treatment, and does not refer explicitly to the conduct of research.

MPs were given a free vote, which excused them from voting along strict party lines. But Bottomley expressed her support for the motion, adding that officials from her department had helped Knight draw up the wording of the amendment. The action has come in for sharp criticism from scientists in the field. Several claim that, whatever Bottomley's feelings on the matter, she should have waited for the HFEA report before making them known - particularly as it is likely to be several years before the techniques are ready for the safe application to humans.

"I am very worried about people who are misinformed producing an ill-drafted amendment in this way," says Roger Gosden of the University of Edinburgh, who works with embryos from animal fetuses. He argues that the current language could be used to "bring down the curtain on research on birth defects and miscarriages". Opponents of the amendment hope that its impact can be blunted by further amendments when it is debated in the House of Lords. 